\title{
Racial Pay Parity in the Public Sector: The Overlooked Role of Employee Mobilization
}

\author{
Isabel M. Perera \\ University of Pennsylvania \\ Desmond King \\ University of Oxford, Nuffield College
}

\begin{abstract}
The rise of economic inequality has aggravated longstanding labor market disparities, yet one exception to this trend stands out: government employment. Here we consider the puzzle of Black-White wage parity in the American public sector. Not only are AfricanAmericans more likely to work in the public sector than in the private sector, but their wages are higher there as well. Building on prior work that emphasizes how institutional factors condition this outcome, we argue that employee mobilization can motor it. As public sector unions gained political influence in the postwar period, their large, Black, blue-collar constituencies advocated for the improvement of working conditions, drawing on both the militant and non-violent tactics of the urbanizing Civil Rights Movement. Archival sources confirm this pattern even at the federal level. The employment and activism of African-Americans in low-skill federal jobs in Washington, D.C. and other cities pivoted trade union attention toward blue-collar issues. This development directly contributed to the enactment of a transparent and universal wage schedule for the bluecollar federal workforce (the Federal Wage System). Events like these helped to improve pay parity for African-Americans, as well as for other disadvantaged groups, including women and people with disabilities.
\end{abstract}

\section{Keywords}

Federal Wage System; Racial parity; Public sector; Social movements; Unions

\section{Corresponding Author}

Isabel M. Perera, University of Pennsylvania, Blockley Hall, Philadelphia, United States: iperera@,upenn.edu 
Despite the persistent rise of economic inequality, public employment remains an engine of mobility and opportunity. ${ }^{1}$ Consider the example of Black workers in the United States. In contrast to the acute inequities of the private sector labor market, the pay, status, and rewards of African-American government employees is closer to that of their white colleagues. Moreover, this relative parity holds even after controlling for public-private differences in occupation and education; and after accounting for efforts to privatize government (which have eroded, but not erased, the trend). ${ }^{2}$ Yet the public sector did not always protect African Americans. In fact, in 1944, Gunnar Myrdal could still describe the "tenuous presence of Blacks in public employment." ${ }^{3}$ Explaining this significant change is the objective of this article.

We trace the enactment of an important tool for pay parity -- a transparent and universal wage schedule for federal blue-collar workers known as the Federal Wage System (FWS) -- to show how Black mobilization within public sector unions directed attention to wage initiatives. ${ }^{4}$ For much of the twentieth century, federal unions ignored the problem of racial equality in public employment. Initiatives to align Black-White earnings were confined to the higher rungs of government service expressed in executive attempts at affirmative action. But from the 1960s, the expansion of the federal government, public sector unionization, and the Civil Rights Movement enabled the growing number of low-wage, unionized, and urban African-American employees to demand better working conditions for blue-collar workers. Their activism pivoted the agenda of one influential trade union, the American Federation of Government Employees (AFGE), toward the enactment of the FWS in 1972. 
Our analysis departs from previous explanations for public sector pay parity to emphasize how employee mobilization helped generate this outcome. In the case of the FWS, employees drew on both the militant and non-violent "repertoires of contention" of the Civil Rights Movement. ${ }^{5}$ Frances Fox Piven and Richard Cloward have argued that the power of the poor rests on militant disruption. ${ }^{6}$ Where traditional forms of advocacy can restrain the full expression of poor interests, mass protest and mobilization does not. The disruptive tactics of Black workers at the 1968 AFGE Convention are a case in point, we contend. Following these workers' mobilization, the union adopted a pro-wage parity stance - but adopted a non-violent, and even color-blind, political strategy. The AFGE became the leading lobbyist for the FWS in Congress, and ultimately made significant concessions for its enactment. Although standard institutional and functional explanations help to explain the durability and efficacy of this legislation, political protest explains its genesis.

\section{Institutional and functional explanations for racial wage parity in the}

\section{public sector}

Extant studies emphasize the causal role of three interrelated institutional factors in creating the "occupational niche" of public sector employment for African-Americans. Following the development of agricultural mechanization in the South and the mass migration of Southern Blacks to the North, competition over private employment increased. Discrimination, segregation, and outright violence regularly denied AfricanAmericans jobs. Some analysts hence proposed that the public sector absorbed Black labor in the absence of private sector alternatives. The concentration of these jobs in 
municipalities with large Black or minority populations, moreover, made it both economically and politically expedient to hire African Americans in city government. ${ }^{7}$

Other scholars note, secondly, that the American State is now a "model employer." The visibility, centralization, and autonomy of government practice, combined with the often-presumed absence of a discriminatory legacy, made these new positions fairer than those offered by older, more fragmented private industries. ${ }^{8}$ As Walker and Bennett observe, "although seldom acknowledged in public debate about the public sector, the public sector is a location for fairer treatment for non-white workers," a quality which motivates some of the opponents of public sector unions in the 2010s. ${ }^{9}$ The reputational costs of practicing opaque hiring procedures and the impulse to standardize prompted officials to implement equal opportunity procedures widely, especially when facing civil rights demands. ${ }^{10}$ The archetypical example of the wage schedule limits individual pay negotiations within each class of pay, and thus prevents supervisors from indiscriminately raising pay for favored workers. Vulnerable workers, such as African Americans and women, are better protected from underpayment. The implementation of a similar practice in the private sector would require, at the very least, a strong directive from the Labor Department, or more realistically, strong legislation from Congress with regulatory enforcement.

The security of government work is related, thirdly, to the vitality of public sector trade unions. Despite the generalized narrative of organized labor's decline, public sector unions have high membership rates. The union membership rate of American government workers (34.4 percent) is more than five times that of private sector workers (6.5 percent). Compare these contemporary statistics to those of 1973 , when rates of public and private 
unionization were approximately equivalent ( 23 percent in the public sector, 24 percent in the private sector). ${ }^{11}$ Public sector unions have raised their political profile, too. The largest campaign spender of 2010, for instance, was the American Federation of State, County and Municipal Employees, whose contributions exceeded even those of the U.S. Chamber of Commerce. ${ }^{12}$ While the trade unions that represent private sector workers, once vigorous, have attenuated nearly to the point of disappearance, those that represent workers in the public service have tended to maintain and develop their position (though of course encountering attacks from Republican leaders). ${ }^{13}$

Each of these explanations has its limits, however. Some scholarly research challenges the perceived certainty of racial fairness in government employment. ${ }^{14}$ Some of the most densely unionized public administrations were reluctant to include Black "newcomers," and deliberately limited opportunities for advancement. ${ }^{15}$ Furthermore, the standardization of wages across the public sector is still aspirational. ${ }^{16}$ Pay for public employees remains differentiated across and within municipal, county, state, and federal levels. Moreover, the mere vitality of public trade unions cannot independently explain the security of public employment, particularly for Black Americans. Not only were some government unions historically hostile to Black workers, the acceleration and accretion of attacks against public unions since the 1980s now threatens the viability and quality of government work. ${ }^{17}$ In fact, the bile toward public sector unions described in Arlie Hochschild's and Katherine Cramer's books are in part coda for African Americans who belong to them, mirroring a long standing White view that Blacks disproportionally consume welfare and state benefits. ${ }^{18}$ 
The institutional and functional explanations instead work in consort when we introduce the mechanism of employee mobilization - a crucial political factor. ${ }^{19}$ As the federal government expanded in the District of Columbia, as state governments expanded in the capitals, and as municipal governments expanded in cities, so too did demand for low-skill public labor. Increasingly, urbanized African Americans filled this demand; against the political backdrop of mounting civil rights and public sector labor movements. These otherwise marginalized workers drew on the more militant repertoires of contention of the Civil Rights Movement to direct union attention to the inadequacies and irregularities of their employment. After some deliberation, the strengthening unions responded with a firm commitment to standardizing pay and practice across government, particularly for low-skill blue-collar workers. In so doing, the union leadership drew on other (non-violent, and even color-blind) repertoires of the Civil Rights Movement. Consistent with the theory and practice of social protest articulated by scholars such as Tarrow, Tilly, and Piven and Cloward, this protective Black occupational niche is substantially the product of African Americans' activism in their unions.

\section{The case of the FWS}

We document the influence of employee mobilization on Black public sector workers' pay parity by tracing the creation of a government pay scale. Wage schedules can promote equality in earnings by offering workers transparent benchmarks of wage minima, and by leveling the overall distribution of earnings. The effects of such scales can go beyond their industries, too. In fact, Rebecca Oliver finds that the maintenance of a given level of macroeconomic wage equality is more likely in countries with extensive pay scales. ${ }^{20}$ 
Trades unions hence tend to favor wage schedules (though they are not always responsible for their creation).

For over a century, the U.S. federal government has relied on wage scales to set the wages of its employees according to the prevailing rate of pay for comparable work in the private sector. But implementation of this principle has been neither universal nor uniform. The government first established the prevailing wage for federal navy yard workers during the Civil War. Congress then extended it to the Government Printing Office in the 1924 Kiess Act, to Tennessee Valley Authority workers in the 1933 TVA Act, and to nonindustrial (classified) federal employees in the 1923 Classification Act, the 1949 Classification Act, and the 1962 Salary Reform Act. Procedures for setting pay include unionized collective bargaining, a wage conference process that includes employee representatives, and an executive committee of political appointees, respectively.

The FWS, the wage schedule for federal blue-collar workers and our empirical focus for its racial implications, was a relative latecomer to federal pay-setting. ${ }^{21}$ Enacted in 1972 , the scale sets pay by determining the local prevailing wage in comparable private sector occupations. ${ }^{22}$ Although pay varies by area (and Congress restrains system-wide pay increases), earnings and protections under the FWS can be more attractive to Black workers than those of the private sector, where racial labor market disparities are sharper. Of particular note is how this system protects workers in rural labor markets, including those of the Deep South. In Alabama, for example, Black-White wage differences are smaller for federal blue-collar workers than clerical and white-collar workers (who benefit from a nationally-set pay scale, the General Schedule) ${ }^{23}$ Here, FWS employees earn the 
prevailing wage afforded to private sector employees in metropolitan areas, but apply it to areas with lower cost of living.

Trades unions help to protect this system in two ways. First, they are involved in setting pay by conducting local wage surveys of comparative private jobs. These surveys advise agencies on pay determination procedures in their local wage area. At the national level, a joint labor-management Federal Prevailing Rate Advisory Committee -- whose members also include labor unions and an independent Chairman (as well as agency representatives) -- oversees these activities. Second, trade unions can use the system as a reference point to hold management accountable in instances of pay discrimination. ${ }^{24}$ The system provides a standard by which workers can advocate for fair compensation.

Among the most involved unions is the AFGE, which as we will show, played a historic role in the system's enactment. The following pages document how the mobilization of Black AFGE members prompted the union to pursue the enactment of the FWS. Although the union sought this goal through institutional channels, the sharp shift in union attention to the demands of Black, blue-collar federal workers is best explained by the militant mobilization of these employees at the union's contemporaneous conventions. We confirm this development through the extensive analysis of primary archival sources, most notably a memoir of union leadership documenting its history (Nevin and Nevin's 1976 AFGE -Federal Union: The Story of the American Federation of Government Employees), the published legislative and regulatory material that led up to and followed the enactment of the Federal Wage System (1967-1982), and a survey of the Washington Post column, the Federal Diary, which followed developments in the federal workforce closely during this time. 


\section{Whites and women in federal trade unions: the origins of the AFGE}

In its early years, the AFGE paid little attention to Black and blue-collar issues, in part because the group ironically had opted out of organizing craft workers. Its predecessor within the American Federation of Labor (AFL), the National Federation of Federal Employees (NFFE), had attempted a large-scale organizational drive in 1931 to recruit craftsmen in the federal service. Other AFL craft unions, however, successfully challenged the move. When the AFL ruled in favor of the craft unions, most of the NFFE membership voted to leave the AFL via referendum. A few members -- mostly white-collar members of the DC-area locals - opposed the exodus. Upon appealing the decision, they earned an AFL charter for a new affiliate: the AFGE. The result was a federal trade union whose membership was overwhelmingly White. ${ }^{25}$

Recruiting new members was difficult. Clientelism pervaded the civil service. Although the Pendleton Act of 1883 helped to establish more meritocratic employment, much of the spoils system was still in place. Furthermore, the onset and protraction of the Great Depression constrained the union's potential membership. Consider the severity of the personnel cuts enacted in 1932 and 1933 (the Economy Acts): pay reductions of 15 percent for most federal employees (including the President and Vice President), onemonth yearly no-pay furloughs for employees earning more than $\$ 1,000$ per year, suspended promotions, limited vacancies, terminated overtime pay, and compulsory retirement. $^{26}$

Note that these government practices drew AFGE attention to women's issues. Women were among the most affected by the Economy Acts, since Congress ordered that 
agencies lay off members of married couples jointly employed by the federal government before any others. ${ }^{27}$ Wives, whose labor the government often under-valued and underpaid, were more likely than their husbands to receive a pink slip. The AFGE began to represent female federal workers, and even promoted them to high levels of union leadership, including the Executive Council. ${ }^{28}$ Prioritizing gender discrimination issues, the union's policy agenda included, for example, a Maternity Leave Bill that passed in the Senate in $1949 .{ }^{29}$

The AFGE's engagement with gender equity did not translate into a concern with racial equity. Racism was no more foreign to public sector unions than it was to private sector unions, where both animosity from White workers and the segregation of American workers into "Black" and "White" jobs purposefully prevented inter-racial organizing. ${ }^{30}$ Within the AFGE, locals appear to have maintained more integrationist policies - a practice that distinguished the union from some of its sister organizations. ${ }^{31}$ The union's selfpublished historical account only identifies one attempt to promote the rights of its African American members during this period: a Bill of Rights drafted in 1938 "for the protection of some 8,000 Negroes employed by the Federal and District of Columbia governments." ${ }^{.32}$ The absence of additional information about the charter in the account suggests that these plans soon evaporated.

\section{Affirmative action for white-collar service}

Racial equity was not a genuine priority for the federal government, either. The postwar expansion of the federal workforce did, however, compel President Kennedy's Democratic Administration to project an image of fair employment in the federal service. ${ }^{33}$ Previous 
administrations had taken an interest in minority hiring, but it was President Kennedy's initiatives in 1961 that responded to the growing demands of the Civil Rights Movement and gave some ballast to reforming hiring practices. ${ }^{34}$ Executive Order 10925 merged the Committee on Government Contracts and the Committee on Government Employment Policy into a new presidential committee: the Committee on Equal Employment Opportunity.

The executive order was a calculated, top-down political move. The appointment of the Vice President Lyndon Johnson as the initiative's Chairman intended to build the Texan's liberal reputation - even though he himself was reluctant to devote resources to the policy. ${ }^{35}$ In an interview, the Executive Director of the Committee (later, Commission), John G. Feild, recalled the Vice President stating at one meeting: "Let's be careful about that damn budget. Let's reconsider that whole question. I never had any notion [that] we [were] going to be getting into all of that money right now." ${ }^{36}$ Raising the issue with President Kennedy, who "accepted" the budgetary strain, made little difference. ${ }^{37}$

Accordingly, the executive order was more concerned with advancing a raceconscious image of the executive than with attending to the demands of African American civil rights groups. ${ }^{38}$ Feild admitted that the NAACP (National Association for the Advancement of Colored People) only had limited involvement in the development of the order. When asked if any civil rights leaders were "brought in" to the project, Field responded that only "at the very later stages" was Roy Wilkins, then executive secretary of the NAACP, consulted to give it an "extra push." ${ }^{39}$ Control over the earlier stages of the process, from the conception to the drafting of the order, remained in the White House.

Promoting African Americans to higher levels of federal service, strategists 
believed, could result in electoral gain. In an interview with political scientist Samuel Krislov, Louis Martin, the African-American director of the minorities division of the Democratic National Committee, admitted that high-profile appointments had a far larger political impact than statistics. "Hell, I even had a [Black] candidate for Secretary of State," Martin remarked. ${ }^{40}$ These elite, white-collar appointments diverted both the Presidency and the public from the racial inequities present elsewhere. The limited attention and political will of the executive on the issue, combined with the reluctance of federal unions to advocate more forcefully for African Americans, therefore restricted the Commission's ability to transform Black federal employment. ${ }^{41}$

\section{The expansion of Black federal employment}

Despite the Commission's limited goals, the Black federal workforce ultimately expanded

- but for other reasons. First, the postwar expansion of the federal government significantly increased the number of available public positions. The growth of government during the Second World War (and then again during the Vietnam War) produced greater opportunities in public sector jobs for women, who the government mobilized in the absence of White men, and African Americans, who had limited enlistment opportunity in the Armed Services in the 1940s (and lost out on the GI Bill benefits); African Americans were of course conscripted for Vietnam. Crucially, as Jennifer Laird has noted, the large supply of new jobs did not displace White men. Otherwise the expansion would have faced the possibility of reversal. ${ }^{42}$

The enactment of the Civil Rights Act in 1964 justified the distribution of many of these new jobs to African Americans. The Act, which empowered the U.S. Department of 
Justice to investigate and prosecute discrimination and other abuses of citizens' rights, extended these rights to federal government employees under Section 717. To monitor and enforce this directive, Congress charged the US Civil Service Commission with the task of investigating complaints and issuing judgments, and created a new agency, the Equal Employment Opportunity Commission (EEOC), to regulate against discrimination in employment. The new agency's modest enforcement authority, however, compelled Congress to then strengthen its powers in the 1972 Equal Employment Opportunities Enforcement Act. This second Act allowed the EEOC to "sue employers in Federal district courts who failed to respond to orders." ${ }^{" 43}$ Taken together, the postwar federal legislation helped to protect Black workers from discrimination, both in the private and public sectors.

Importantly, the geographic concentration of these jobs in Washington, D.C. promoted opportunities for the city's African-American residents. In his study of Black federal employment, Krislov notes the "striking" difference between the employment of African Americans in central headquarters and in the regions. He reports that African Americans constituted about one in eight federal employees in 1965, but in the Washington area, they constituted nearly one in four.

The prominence of DC-based public sector jobs for African Americans nationally stands out against more general labor patterns as well. ${ }^{44}$ Black federal employment also grew in other northern cities, and in specific agencies. For example, King tracked the number of Black federal workers in Chicago employed under the General Schedule, and found that they more than doubled, jumping from 94 to 219, between 1956 and 1960 . Meanwhile in Mobile, where discriminating labor markets had expelled AfricanAmericans northward, the number stayed the same: $0 .{ }^{45}$ Moreover, disparities in hiring 
practices within the federal service led to more favorable conditions for Black workers in some agencies than in others. Krislov compared the centralized and aggressive system of settling complaints at the Veterans' Administration, for instance, to the opaque promotional practices of the Patent Office. The former reduced discrimination, promoted African Americans to higher rungs of service, and raised the agency's profile as an equal opportunity employer - so much so that Ebony magazine called the Veterans Administration "the government's most integrated agency." 46

Most of the newly hired African Americans, furthermore, worked in blue-collar jobs. Between 1965 and 1967 the percentage of African Americans employed at lower grades (General Schedule 1-4) increased by over 10 percent at the Interstate Commerce Commission, the Information Agency, and the Government Printing Office, while their representation at higher grades (General Schedule 12-18) in these agencies rose by less than half a percentage point ${ }^{47}$ That said, Washington contained nearly half of the Black high-skill federal workforce (General Schedule 12-18) at the time; but this was a function of the higher overall employment of African Americans in DC-based federal agencies. Washington also contained, by extension, greater numbers of Black low-grade and bluecollar employees than elsewhere. ${ }^{48}$

\section{Black mobilization within the AFGE}

The growing presence of African Americans in blue-collar jobs offered federal unions the opportunity to expand their membership by organizing these new workers. Few unions stirred, however. In the case of the AFGE, the decision to integrate Black members, and to incorporate Black demands was the product of contentious Black politics within the 
organization. Against the backdrop of the fomenting Civil Rights Movement of the 1960s, racism paralyzed the largely blue-collar Local 361 at the National Naval Medical Center in Bethesda, Maryland to the point of receivership. ${ }^{49}$ Ralph Biser, a former auto repairman and Metal Trades Unionist, decided to establish a multi-racial board - despite the anxieties and protests of some colleagues. The initiative succeeded, and propelled Biser to the leadership of District 14 (the greater Washington area), in which role he prioritized the needs of African American and blue-collar members. He also diversified District leadership. During Biser's tenure, the National Representatives of District 14 included White and Black men, as well as White and Black women. Subsequently, Biser prepared African American unionist Major Travis to take his place as head of the district. The promotion of workers from underrepresented groups to higher levels of office was not immediately welcomed by the national office, but assured the development of District 14 .

A race-conscious protest vote by Biser and his DC allies in 1962 was the first step toward changing the union's national level strategy on race and blue-collar wages. That year, the group opposed the election of John Griner, but ultimately agreed to accept his leadership in exchange for several concessions - including, critically, the union-wide adoption of Black and blue-collar policy issues. According to Biser, this ensured that Griner could "open many doors to my people which had been denied to them before." Importantly, the Griner-Biser agreement also produced the union's "pioneering" Fair Practices Department, a Black-led national office to protect union members from discrimination and unfair treatment; as well as the Wage Board Department, whose "most important and major objective" was the enactment of a transparent, unified wage schedule for blue-collar workers. By channeling the priorities of Black members in District 14 to the 
national union policy agenda, the Biser-Griner agreement re-directed union attention to blue-collar issues.

Several other factors supported Griner's decision to direct union attention to African American and blue-collar issues. First, there was a jurisdictional void left by the AFGE's rival union, the NFFE, whose membership was largely white-collar and at management level. ${ }^{50}$ Second, the recent enactment of civil rights legislation empowered African American federal workers (and the unions that represented them) to protect their gains. ${ }^{51}$ Third, an Executive Order signed by President Kennedy in 1962 extended some collective bargaining rights to federal unions, and in doing so, permitted a shift in tone and tactics. ${ }^{52}$ These factors laid the groundwork for the AFGE's landmark campaign to enact a wage schedule for blue-collar federal workers.

\section{The AFGE and the campaign for racial wage parity}

By 1967, the union made the leap from agenda-setting to action. Drawing on the nonviolent repertoires of contention promoted by Civil Rights leaders such as Martin Luther King, Jr., it aimed to reform the non-statutory method of setting pay for blue-collar federal employees (the coordinated Federal Wage System) through an institutional channel: congressional legislation. The initial bills (HR 318 and S. 2303) proposed that local area wage boards, led by chief agency officials, conduct regional surveys of the prevailing rate of private sector pay across the blue-collar occupations. Drawing on the results of these surveys, area wage boards would then propose a 10-step wage grade plan for each occupational category to the Federal Wage Board Council - composed of employees and representatives, and led by the Civil Service Commissioner -- for approval. Although the 
NFFE (whose membership had also moved further to the Left by then) protested the weak role of the Council, neither the administration nor private labor unions favored centralizing the wage-setting system. AFGE opted to appease private unions on this issue in exchange for their political support on the broader legislative campaign. ${ }^{53}$

So enthusiastic was the AFGE membership about this campaign that the hearings drew an unprecedented number of observers. "Over 150 people," estimated Senator Mike Monroney (D-OK, then-Chairman of the Committee on the Post Office and Civil Service), were "unable to find seats." 54 The raucous crowd represented the many Black and bluecollar workers members of the AFGE. By then, nearly half of the union's membership worked low-skill and blue-collar federal jobs (45 percent of their 240,000 members). ${ }^{55}$

Although the union attempted to present its activism as color-blind (a strategy the AFGE adopted in these times of bitter civil rights struggles), this outward stance belied the strong racial implications and overtones of the union's advocacy. Explicit allusions to race are notably absent from the legislative hearings. Instead, the testimony of Royal Sims - the union's most prominent Black member (a national vice president) and a perceived racial moderate ${ }^{56}$-- highlighted three areas of the Veterans' Administration (his employer) that called "rather emphatically for improvement...the laundry service, the housekeeping service, and the dietetic service." ${ }^{57}$ Few areas of the American labor market were more profoundly racialized than these "domestic" services. In fact, historically holders of these jobs were excluded for racial motives from participating in the social programs that otherwise improved American work and welfare conditions. ${ }^{58}$ Moreover, when Sims cited the below-poverty rates of pay for laundry service workers in Dallas, Nashville, Roanoke, 
and Shreveport ( $\$ 1.37$ an hour, nearly 10 cents below the poverty line of $\$ 1.48$ an hour), he depicted a piercing image of wage inequality in the segregated South.

The implications of the trade union's agenda for racial equality notwithstanding, many Black members were critical of the timidity of its color-blind approach. At the next AFGE Convention in the tumultuous year of 1968, African-Americans mobilized again in protest, drawing on the power of disruption and the more aggressive repertoires of contention promoted by Civil Rights leaders such as Malcolm X. Dissatisfaction was spreading across the organization: this time, militants from Philadelphia joined those from Washington. Convening secret meetings that threatened to "blow this convention wide open," 900 Black delegates charged Griner with ignoring racial issues, Sims with colorblindness, and the AFGE as a whole with conservatism. ${ }^{59}$ When the union voted to adhere to its no-strike pledge, nearly a hundred Black delegates openly protested. ${ }^{60}$

Sims and Griner responded immediately. Almost overnight, they hatched a program that satisfied the Black workers' demands. By the convention's conclusion, Black delegates from Washington once again supported Griner, while those from Philadelphia withdrew their disapproving comments about Sims. ${ }^{61}$

The limited documentation of the Sims-Griner plan obscures its details -- but it is clear that the pace and progressivity of the federal wage board reform escalated after the protest. ${ }^{62}$ The following year, the number of wage board bills introduced in Congress doubled those introduced in the prior two years. ${ }^{63}$ The new bills also went further than before by extending the wage schedule to 100,000 non-appropriated fund employees, ${ }^{64}$ increasing pay for nightshifts and travel time, and weakening the authority of the Civil Service Commission in wage setting. The revised Council, these bills proposed, would 
replace the Civil Service Commissioner with an impartial chairman (drawn from neither labor nor management).

As the pace of hearings accelerated, so too did the Republican Administration's opposition to the bill. Management preferred a system of administrative control to one of legislative obligation. ${ }^{65}$ Although the initiative generally found favor in the Democratically-controlled Congress, virtually every representative of the American State - ranging from the Chairman of the Civil Service Commission to an Assistant Secretary of Defense -- denounced the "inflexible" bill. ${ }^{66}$ An 8-day wildcat strike in March 1970 by U.S. postal workers stoked tensions further. When Nixon terminated the strike by granting workers both a pay raise and the right to collective bargaining, bullish blue-collar workers within the AFGE pressured their representatives to capitalize on the President's apparent turn of mind. ${ }^{67}$

The $91^{\text {st }}$ Congress hence hurried to pass legislation "tailored" to meet the approval of the President in its closing days. ${ }^{68}$ The bill that passed on December 15, 1970 reduced the number of steps from 10 to 4, excluded non-appropriate fund employees, and offered no additional compensation for night shift employees. ${ }^{69}$ Yet a veto followed two weeks later. A monetarist, President Nixon asserted that the "fires of inflation are fueled" when the rising federal wages compelled private wages to do the same. ${ }^{70}$ Increasing spending, he also argued, would lead to job cuts -- particularly in the heavily blue-collar Defense Department, where employee support for the bill was high. (Nixon frequently gave lipservice to progressive social policies and then either sidelined or rejected them. $]^{71}$

The presidential veto, however, did not stop the legislative momentum. On the contrary, House members introduced 18 new bills from January to March 1971. Other 
unions (machinists, post office employees, and even the Service Employees International Union) joined the AFGE in solidarity. Labor leaders drew explicit attention to the agitated mobilization of employees, too: "We are being faced with a grave situation," Griner implored, "Militancy among this group of employees is on the increase. All they are asking for is justice and equity. I say to you, they are not getting justice and equity." 72 The workers' renewed vigor won results. A second bill, more progressive than its predecessor, passed Congress in August 1972. This one included five within-grade pay steps, the nightshift differential, an impartial Council chairman, and importantly, the nonappropriated fund employees. Congressional and union enthusiasm aside, observers doubted whether Nixon would approve the new bill. ${ }^{73}$

In a startling about-face, the President signed Public Law 92-392 on August 19, 1972. Contingency intervened. Griner had made an arrangement. Bidding for second term votes in the early days of the Watergate revelations, Richard Nixon agreed to sign the bill in exchange for the labor leader's personal endorsement of his candidacy. ${ }^{74}$ (Griner did not go so far, however, as to tender the union's formal support for a Republican campaign.) The bill had immediate effects for African Americans in federal service. In the 1970s, about half of lower-grade blue-collar employees were Black (double that statistic for white collar workers). ${ }^{75}$ The significant achievement for the union's mobilized Black members was a product of both disruptive and institutional techniques of social protest.

\section{Discussion and conclusions}

The Federal Wage System undoubtedly improved the quality of blue-collar government work, but it retained deficiencies. First, labor leaders conceded several desirable policy 
changes (e.g., travel and overtime pay, the inclusion of contracted private employees), and, in the case of AFGE President Griner, a Republican endorsement as well. Second, the implementation of the FWS permitted some pay disparities to remain. Employees in rural areas benefit more than those in urban areas, where limited wage increases struggle to keep pace with the high cost of living. Moreover, the government's subsequent expansion of private contracts and market-oriented approaches to public management has narrowed the influence of the FWS (especially in the crucial Departments of Defense and Veterans Affairs) ${ }^{76}$ Third, some wage schedules reduce inequalities more than others. ${ }^{77}$ Although the white-collar General Schedule suffers from cumulative underpayment problems and a significant pay disparity against private sector work, racial wage differences are less than in the blue-collar FWS. ${ }^{78}$ On average, African Americans in the General Schedule system earn 89 percent of Whites, while those in the FWS system earn 84 percent of Whites. ${ }^{79}$ The local determinations of pay in the FWS exaggerate this disparity for blue-collar federal workers (the General Schedule, by contrast, sets uniform pay rates at the national level). Finally, these "good government jobs," as Frederick Gooding, Jr. has written, rendered Black public servants "better off than those blacks who remained trapped in depressed southern economies, [but] they were nonetheless consistently restricted from upwardly mobile economic and social growth opportunities. ${ }^{~}{ }^{80}$ In short, equality cannot rest on the prop of public sector work in an otherwise racially unjust economy.

Even with these limitations, however, the reforms illustrate important dimensions of social movement theory. Drawing on both the militant and non-violent repertoires of contention of the Civil Rights Movement, protestors first shifted elites' political agendas and then allowed them to compromise with their adversaries ${ }^{81}$ Systems of oppression are 
unlikely to meet all of the demands of the protestors. Moreover, concessions are likely to disarm a movement; and the mobilization of the AFGE's Black militants appears to have peaked during the campaign to enact the FWS. Nonetheless, the protests of the poor or politically marginal can result in a tangible political change: in this case, it was the legislative enactment of a wage schedule for blue-collar federal employees. That the protestors were composed of Black union members forbidden even from striking demonstrates the potency of disruption for shifting public discourse and policy. ${ }^{82}$ Although the FWS strayed from the movement's radical origins, "modest concessions," as Piven and Cloward wrote, "demonstrate that protest "works." 83

This is not the first article to demonstrate how identity-based social movements within the public sector can redress economic and social injustices, if only to a limited degree. In fact, research has renewed attention to this pattern. In There's Always Work at the Post Office (2010), Philip Rubio demonstrates how Black postal workers drew on the political techniques of civil rights and labor unionism to protest inequality in the workplace. Their advocacy played a critical role in the wildcat strike of 1970, and in the subsequent enactment of collective bargaining rights for postal workers. Gooding's recent book (2018), too, documents the postwar struggle of DC-based Black federal workers to secure and protect quality employment, despite ongoing resistance from Whites, administrators, and the structural biases of the broader political economy. Moreover, this line of research goes beyond Black mobilization. Lee Ann Banaszak shows how women in the public sector stealthily advanced gender equality and in his forthcoming book, Rick Valelly examines how LGBT activists used similar tactics to level inequalities in public sector work as well. ${ }^{84}$ 
The renewed scholarly attention to the historical mobilization of marginalized public sector workers also draws attention to how weak organization could impact contemporary America. Unions in the public sector reduce wage inequality by 16.2 percent for U.S. males and by 10.7 percent for U.S. females - far more than unions in the private sector (which reduce male inequality and female inequality only 1.5 percent and 0.6 percent, respectively). ${ }^{85}$ Attacks on public sector unionism threaten to reverse these trends. ${ }^{86}$ Moreover, the restructuring and privatization of public employment could endanger the Black middle class, whose economic mobility rests disproportionately on that sector. ${ }^{87}$ This very disproportionate return to African Americans working in the public sector, many of whom belong to unions, informed the GOP-orchestrated anti-public sector union strategy manifest in several states in the 2010 s, notable Wisconsin and Indiana. ${ }^{88}$ Wisconsin's Governor Republican Scott Walker, in office between 2011 and 2019, was a key protagonist whom many critics accused of fanning racist politics in his prolonged efforts to dilute public sector union rights and power ${ }^{89}$ Walker mobilized around the 'right to work' anti-union law, a scheme originating with a racist anti-union movement orchestrated by far-right white supremacists in the Texas oil industry and their supporters in the 1940s. ${ }^{90}$ In Wisconsin, right to work laws weakened unions and the public employees they represent. ${ }^{91}$ Hannah Walker and Dylan Bennett find that appeals to racial animus by the Scott Walker administration informed its attack on public sector unions, with large African American memberships, and on collective bargaining rights. The administration's rhetoric and proposals were "inherently racialized," contrasting "public employees as lazy" compared with the moral superiority of private sector workers: elite narratives constructed "private workers as deserving and public workers as undeserving" articulating a "new 
expression of an entrenched thread in American political history, situating the white workers in opposition to the non-white worker." ${ }^{92}$

The public sector is an important occupational niche for other groups as well, including women, people with disabilities, and veterans. ${ }^{93}$ For example, female workers in the general labor market earn about 82 percent of their male counterparts. This ratio is more favorable for those in government employment: under the Federal Wage Schedule specifically, women earn about 85 percent of men. ${ }^{94}$ As the organizational clout of public workers declines, so too would opportunities for the advancement of several marginalized groups.

What Michael Katz characterizes as the "most powerful vehicle of economic mobility for African Americans," - the public sector and public employment - was not always so, in our view. ${ }^{95}$ Nor is the Black occupational niche of public employment simply the product of institutional conditions. The migration to urban centers of public work, the vitality of public sector unions, and the tendency of government to "model" fair employment facilitated, but did not guarantee, the improvement of wage equality in government work. Rather, this outcome results from the contextually-specific mobilization of Black, blue-collar federal employees and their union leadership. To substantiate this thesis, we documented the development of the Federal Wage Schedule. Growing numbers of Black, blue-collar federal workers in Washington, D.C. pivoted the attention of their newly empowered trade union, the American Federation of Government Employees, toward racial workplace concerns, and with them, the enactment of the Federal Wage Schedule: a crucial policy tool for securing fairer pay.

\section{Acknowledgments}


We gratefully acknowledge the comments of those who attended the panel "A Good Government Job? Racial Equality and the Public Sector" at the 2018 Meeting of the American Political Science Association, especially Paul Frymer, and of Trevor Brown, Wayne Coleman, Brian DeWyngaert, Katie Rader, Sidney Tarrow, and George Wilson. Errors remain our own.

\section{Declaration of Conflicting Interests}

None

\section{Funding \\ N/A}

\section{Notes}

\footnotetext{
${ }^{1}$ The public sector wage premium has been stable for decades in the United States, see Lawrence Katz and Alan Krueger, "Changes in the Structure of Wages in the Public and Private Sectors" (Cambridge, MA: National Bureau of Economic Research, March 1991), https://doi.org/10.3386/w3667. For a discussion of this trend cross-nationally (and its effects on overall wage inequality), see David Rueda and Jonas Pontusson, "Wage Inequality and Varieties of Capitalism," World Politics 52, no. 3 (April 2000): 350-83, https://doi.org/10.1017/S0043887100016579.

${ }^{2}$ Jennifer Laird, "Public Sector Employment Inequality in the United States and the Great Recession," Demography 54, no. 1 (February 2017): 391-411, https://doi.org/10.1007/s13524-016-0532-4. For an analysis of how recent developments in public sector management are broadening racial wage inequality, see George Wilson, Vincent J. Roscigno, and Matt Huffman, "Racial Income Inequality and Public Sector Privatization," Social Problems 62, no. 2 (May 2015): 163-85, https://doi.org/10.1093/socpro/spv001. ${ }^{3}$ Gunnar Myrdal cited in Michael B Katz, Why don't American cities burn? (Philadelphia: University of Pennsylvania Press, 2012), http://public.eblib.com/choice/publicfullrecord.aspx?p=3441953, 73.

${ }^{4}$ In this article, we use the terms pay, wages, and earnings interchangeably.

${ }^{5}$ On repertories of contention, see Sidney G. Tarrow, Power in Movement: Social Movements, Collective Action, and Politics, Cambridge Studies in Comparative Politics (Cambridge [England]; New York: Cambridge University Press, 1994); Charles Tilly, Popular Contention in Great Britain, 1758-1834 (Cambridge, Mass: Harvard University Press, 1995).

${ }^{6}$ Frances Fox Piven and Richard A. Cloward, Poor People's Movements: Why They Succeed, How They Fail (New York: Vintage books, 1979).

${ }^{7}$ Eisinger (1982) "Black Employment in Municipal Jobs: The Impact of Black Political Power." American Political Science Review (76)2: 380-392; Anthony Downs, Inside Bureaucracy (Boston: Little, Brown, 1967); O’Brien, K. M. (2003). 'The Determinants of Minority Employment in Police and Fire Departments.' The Journal of Socio-Economics 32(2): 183-195.

${ }^{8}$ See Krislov, The Negro in Federal Employment, 91, for a discussion and critique of this point.

${ }^{9}$ Hannah Walker and Dylan Bennett, "The Whiteness of Wisconsin's Wages: Racial Geography and the Defeat of Public Sector Labor Unions in Wisconsin.” New Political Science 37 (2015): 181-203, p202.

${ }^{10}$ Desmond King and Robert C. Lieberman, "Ironies of State Building: A Comparative Perspective on the American State," World Politics 61, no. 03 (July 2009): 547-88, https://doi.org/10.1017/S0043887109000185; Desmond King and Marc Stears, "How the U.S. State Works: A Theory of Standardization," Perspectives on Politics 9, no. 03 (September 2011): 505-18, https://doi.org/10.1017/S1537592711002726; Laird, "Public Sector Employment Inequality in the United States and the Great Recession," 393.; On the role of social movements, see Larry Isaac and Lars Christiansen, "How the Civil Rights Movement Revitalized Labor Militancy," American Sociological Review 67, no. 5 (October 2002): 722, https://doi.org/10.2307/3088915; Larry Isaac, Steve McDonald, and Greg Lukasik, "Takin' It from the Streets: How the Sixties Mass Movement Revitalized Unionization," American Journal of Sociology 112, no. 1 (July 2006): 46-96, https://doi.org/10.1086/502692.
} 
11 "Union Members Summary,” Bureau of Labor Statistics, January 19, 2018, https://www.bls.gov/news.release/union2.nr0.htm; M. S., "Public and Private Unions: What's the Difference Exactly?," The Economist, February 9, 2011, sec. Democracy in America, https://www.economist.com/democracy-in-america/2011/02/09/whats-the-difference-exactly.

For the historical and political context of union membership patterns, see Michael Goldfield, The Decline of Organized Labor in the United States (Chicago: University of Chicago Press, 1987).

${ }^{12}$ To support organizing efforts in 2018 battleground states, moreover, the union joined forces with teachers, the AFL-CIO, and a Democratic mega-donor to found the super PAC "For Our Future." The group raised $\$ 50$ million in 2016, and subsequently another $\$ 10$ million, according to Federal Election Commission Records. During the same time period, "Voices of the AFGE," another public employee super PAC, spent over \$5 million. "For Our Future (ID: C00620971)," Federal Election Commission, 2018 2015, https://www.fec.gov/data/committee/C00620971/?tab=summary\&cycle=2016.; Gabriel Debenedetti, “Giant Labor-Backed Group Plans \$70M Midterm Blitz," Politico, January 19, 2018, https://www.politico.com/story/2018/01/19/for-our-future-2018-midterms-349351; The Voices of the American Federation of Government Employees (ID: C00512293)," Federal Election Commission, 2018 2011, https://www.fec.gov/data/committee/C00512293/?cycle=2016. ; Brody Mullins and John D. McKinnon, "Campaign's Big Spender: Public-Employees Union Now Leads All Groups in Independent Election Outlays," The Wall Street Journal, October 22, 2010, https://www.wsj.com/articles/SB10001424052702303339504575566481761790288.

${ }^{13}$ The resources public sector unions have enjoyed historically from payroll dues, however, has been eroded recently by the Supreme Court, see Janus v. American Federation of State, County, and Municipal Employees, Council 31, et al, No. No. 16-1466 (Supreme Court of the United Stats $\backslash$ June 27, 2018).

${ }^{14}$ For example, Krislov observed that states with high Black populations (Mississippi, Alabama) were not sites of high Black federal employment.

Krislov, The Negro in Federal Employment, 103-5.

${ }^{15}$ Frances Fox Piven, "Militant Civil Servants in New York City," in Politics/America, ed. W. Burnham (New York: Van Nostrand, 1973), 380-3. And for how racism trammeled unionization generally see Michael Goldfield, The Color of Politics (New York: The New Press, 1997).

${ }^{16}$ On the inability of the American State to enforce labor standards more generally, see Janice Fine, "Enforcing Labor Standards in Partnership with Civil Society: Can Co-Enforcement Succeed Where the State Alone Has Failed?," Politics \& Society 45, no. 3 (September 2017): 359-88, https://doi.org/10.1177/0032329217702603; Janice Fine and Jennifer Gordon, "Strengthening Labor Standards Enforcement through Partnerships with Workers' Organizations," Politics \& Society 38, no. 4 (December 2010): 552-85, https://doi.org/10.1177/0032329210381240.

${ }^{17}$ The fortification of public unions, importantly, has occurred despite racial integration - a factor that otherwise debilitated American trade unions. But today, African Americans participate as much in the public sector labor movement as they do in the private sector labor movement. As in the public sector, in the private sector, African Americans are more likely to join unions, as well as more likely to be represented by unions, than White workers (by about 3 percentage points), Asian workers (by about 4 percentage points), or Hispanic workers (by about 3-4 percentage points) On the impact of racial integration in American unionism, see Paul Frymer, Black and Blue African Americans, the Labor Movement, and the Decline of the Democratic Party, 2011. See also Paul Frymer, "Race, Labor, and the Twentieth-Century American State," Politics \& Society 32, no. 4 (December 2004): 475-509, https://doi.org/10.1177/0032329204269980. On labor union participation rates, see Bureau of Labor Statistics, "Union Members Summary."

${ }^{18}$ Katherine J. Cramer, The Politics of Resentment: Rural Consciousness in Wisconsin and the Rise of Scott Walker, Chicago Studies in American Politics (Chicago!; London: University of Chicago Press, 2016); Arlie Russell Hochschild, Strangers in Their Own Land: Anger and Mourning on the American Right (New York: The New Press, 2018); On welfare racism, see Martin Gilens, Why Americans Hate Welfare: Race, Media, and the Politics of Antipoverty Policy, Studies in Communication, Media, and Public Opinion (Chicago: University of Chicago Press, 1999). Jill S. Quadagno, The Color of Welfare: How Racism Undermined the War on Poverty (New York: Oxford Univ. Press, 1996).

${ }^{19}$ On the importance of political and institutional factors in shaping relative racial earnings and employment, see William Sites and Virginia Parks, "What Do We Really Know About Racial Inequality? Labor Markets, Politics, and the Historical Basis of Black Economic Fortunes," Politics \& Society 39, no. 1 (March 2011): 40-73, https://doi.org/10.1177/0032329210394998. On the sort of mechanisms at work 
here see the account in Doug McAdam, Sidney Tarrow and Charles Tilly, The Dynamics of Contention. (New York: Cambridge University Press, 2001).

${ }^{20}$ Rebecca Oliver, "Diverging Developments in Wage Inequality: Which Institutions Matter?," Comparative Political Studies 41, no. 12 (December 2008): 1551-82, https://doi.org/10.1177/0010414007312837; Rebecca J. Oliver, "Powerful Remnants? The Politics of Egalitarian Bargaining Institutions in Italy and Sweden," Socio-Economic Review 9, no. 3 (July 2011): 533-66, https://doi.org/10.1093/ser/mwq030.

${ }^{21} \mathrm{We}$ also focus on the FWS because the federal government often provides more protections for its employees than other public employers, and therefore exemplifies the security of this occupational niche, see Frank Dobbin, Inventing Equal Opportunity (Princeton, N.J: Princeton University Press, 2009).

22 "An Act to Provide an Equitable System for Fixing and Adjusting the Rates of Pay for Prevailing Rate Employees of the Government, and for Other Purposes," Pub. L. No. 92-392 (1972); U.S. Office of Personnel Management, "Federal Wage System Overview," n.d., https://www.opm.gov/policy-dataoversight/pay-leave/pay-systems/federal-wage-system/\#url=Overview.

${ }^{23}$ Authors' calculations, see "Federal Workforce Data: Diversity Cube," Fedscope, March 2018, https://www.fedscope.opm.gov/.

${ }^{24}$ On the prevalence of policies like pay scales that promote pay transparency, and their effects on labor markets and workplace inequalities, see Emilio J. Castilla, "Accounting for the Gap: A Firm Study Manipulating Organizational Accountability and Transparency in Pay Decisions," Organization Science 26, no. 2 (April 2015): 311-33, https://doi.org/10.1287/orsc.2014.0950; Marlene Kim, "Pay Secrecy and the Gender Wage Gap in the United States," Industrial Relations: A Journal of Economy and Society 54, no. 4 (October 2015): 648-67, https://doi.org/10.1111/irel.12109.; Jake Rosenfeld, "Don’t Ask or Tell: Pay Secrecy Policies in U.S. Workplaces," Social Science Research 65 (July 2017): 1-16, https://doi.org/10.1016/j.ssresearch.2017.01.009; Jake Rosenfeld and Patrick Denice, "The Power of Transparency: Evidence from a British Workplace Survey," American Sociological Review 80, no. 5 (October 2015): 1045-68, https://doi.org/10.1177/0003122415597019.

${ }^{25}$ Jack Nevin and Lorna Nevin, AFGE-Federal Union: The Story of the American Federation of Government Employees, Bicentennial Edition (American Federation of Government Employees, 1976), 7. ${ }^{26}$ Ibid, 26, 30, 68 .

${ }^{27}$ Ibid, 10 .

${ }^{28}$ Ibid, see especially discussions throughout $40-109$.

${ }^{29}$ Ibid, 57.

${ }^{30}$ Philip W. Nyden, "Evolution of Black Political Influence in American Trade Unions," Journal of Black Studies 13, no. 4 (June 1, 1983): 379-98. And see Desmond King, Separate and Unequal: African Americans and the US Federal Government (New York: Oxford University Press, 2007).

${ }^{31}$ Public sector unions that represented workers at the state and county levels (such as AFSCME) allowed southern locals to maintain segregated unions, and integrated those in northern states, see Francis Ryan, AFSCME's Philadelphia Story: Municipal Workers and Urban Power in the Twentieth Century (Philadelphia: Temple University Press, 2011).

${ }^{32}$ Nevin and Nevin, AFGE-Federal Union, 32.

${ }^{33}$ Despite conservative attempts to keep the federal government small, the expansion of the military, welfare, and regulatory states generated expansive employment opportunities, particularly in Washington. Under FDR and the New Deal, Republicans sought to limit the growth of the federal workforce - and sought to prevent repeating that experience under President Truman during the Korean conflict. In 1951, Congress even passed an amendment capping the size of the federal workforce by forbidding federal employers to hire permanent employees. Only temporary hires were tolerated. Yet the effort was not enough to constrain the effects of the mass income tax of the war years and an expanded regulatory state. Between 1951 and 1980, federal employment grew by 24 percent. See Elisabeth S. Clemens, "Distrust in Distant Powers: Misalignments of Political and Social Geography in American Democracy," Items: Insights from the Social Sciences (Social Science Research Council, August 8, 2017); U.S. Senate Committee on Post Office and Civil Service, "Analysis of the Whitten Amendment" (U.S. Government Printing Office, Washington, D.C.: 83rd Congress, 1st Session, March 18, 1953); U.S. Senate Committee on Post Office and Civil Service, "Analysis of the Whitten Amendment," 2.; Kearney and Mareschal, Labor Relations in the Public Sector, 18; On how these efforts contributed to the Civil Rights Movement, see Merl Elwyn Reed, Seedtime for the Modern Civil Rights Movement: The President's Committee on Fair Employment Practice, 1941-1946 (Baton Rouge: Louisiana State University Press, 1991). 
${ }^{34}$ John F. Kennedy, "Executive Order 10925 - Establishing The President's Committee On Equal Employment Opportunity" (Office of the Federal Register, National Archives and Records Administration, March 6, 1981).

${ }^{35}$ Krislov, The Negro in Federal Employment, 61.

${ }^{36}$ Feild, John G. Feild Oral History Interview, 26.

${ }^{37}$ Nevertheless, the Commission attempted to implement affirmative action programs in both the public and private sector. Efforts in the private sector, Feild admits, were inevitably frail. The "Plans for Progress" program partnered with select private companies to expand employment opportunities for African Americans. Confronting Robert Troutman, a lawyer on the commission who advocated this approach as a cost-saving measure, Feild contended: "Bob, we're going to have to have both [affirmative action programs in the private and public sector]... for every one guy [businessman] willing to step forward, there's an awful lot of guys [businessmen] that don't understand it." As a small, non-compulsory program, Plans for Progress could not impel a significant swathe of the private sector to reform hiring practices. Feild, John G. Feild Oral History Interview, 26.

${ }^{38}$ For a discussion of the NAACP's litigation efforts against discrimination in the public sector, see Goluboff in Eric Arnesen, ed., Encyclopedia of U.S. Labor and Working-Class History (New York: Routledge, 2007).

${ }^{39}$ John G. Feild, John G. Feild Oral History Interview - JFK \#1, 1/16/1967, interview by John F. Stewart, Washington, D.C., January 16, 1967, John F. Kennedy Library Oral History Program, National Archives and Records Administration, 23.

${ }^{40}$ Krislov, The Negro in Federal Employment, 37.

${ }^{41}$ Even the unions involved - who were otherwise sympathetic to the project - were cautious about implementation, especially within lower grades. As Feild recalls, "We had complaints from a couple of the union guys about this - that pressures were being put, you know, in one of the post offices to push Negroes ahead of Whites." Feild, John G. Feild Oral History Interview, 40.

${ }^{42}$ Laird, "Public Sector Employment Inequality in the United States and the Great Recession."

${ }^{43}$ Desmond S. King, Separate and Unequal: African Americans and the US Federal Government, Rev. ed (Oxford ; New York: Oxford University Press, 2007), 206-209.

${ }^{44}$ Krislov, The Negro in Federal Employment, 103-5.

${ }^{45}$ King, Separate and Unequal, 234.

${ }^{46}$ Krislov, The Negro in Federal Employment, 130-3

${ }^{47}$ King, Separate and Unequal, Table A3.13, p 240),

${ }^{48}$ Krislov, The Negro in Federal Employment, 104.

${ }^{49}$ Nevin and Nevin, AFGE-Federal Union, 128-130.

${ }^{50}$ See Rung in Arnesen, Encyclopedia of U.S. Labor and Working-Class History; Nevin and Nevin, AFGEFederal Union.

${ }^{51}$ Krislov, The Negro in Federal Employment, 32-33. On the role of militancy in stimulating labor activity during this period, see Isaac and Christiansen, "How the Civil Rights Movement Revitalized Labor Militancy"; Isaac, McDonald, and Lukasik, "Takin' It from the Streets." On the political influence of Black protest on public policy more broadly, see Daniel Q Gillion, The Political Power of Protest: Minority Activism and Shifts in Public Policy (Cambridge: Cambridge University Press, 2013).

52 The order was a diluted version of an earlier bill that had failed in Congress and lacked the support of Kennedy's predecessor, Republican President Eisenhower. Despite its punitive restrictions (e.g., excluding some federal unions, forbidding the topics of wages, benefits, and union security provisions from collective bargaining, and denying the right to strike), the order nonetheless emboldened organized workers to act. Even the more "timid" union, the NFFE, became more combative than in the past. Significant national and local organizing followed, see Rung in Arnesen, Encyclopedia of U.S. Labor and Working-Class History.; Nevin and Nevin, AFGE-Federal Union; John F. Kennedy, "Executive Order 10988 -EmployeeManagement Cooperation in the Federal Service" (Office of the Federal Register, National Archives and Records Administration, January 17, 1962); DiSalvo, Government against Itself, 49-50.

${ }^{53}$ For an overview of the previous system, see "Wage Board Employees" (Committee on Post Office and Civil Service. Senate; 91st Congress, 2nd Session (1970), August 31, 1970), https://congressional-proquestcom.proxy.library.upenn.edu/legisinsight?id=12881-5\%20S.rp.1155\&type=REPORT, 1-4; "Wage Board Employees, Report to Accompany S. 2303" (U.S. Senate Committee on Post Office and Civil Service, October 10, 1967); "Wage Board Employees," § U.S. Senate Committee on Post Office and Civil Service (1967). 
54 "Wage Board Employees," § U.S. Senate Committee on Post Office and Civil Service (1967), 12.

55 "Wage Board Employees," § U.S. Senate Committee on Post Office and Civil Service (1967), 16; Nevin and Nevin, AFGE-Federal Union, 106; Mike Causey, "Union Votes Down Move to Drop No-Strike Vow," The Washington Post, September 12, 1968, sec. Federal Diary.

Nevin and Nevin, AFGE-Federal Union, 106; Mike Causey, "Union Votes Down Move to Drop No-Strike Vow," The Washington Post, September 12, 1968, sec. Federal Diary.

${ }^{57}$ Sims in "Wage Board Employees," § U.S. Senate Committee on Post Office and Civil Service (1967), 31.

${ }^{58}$ Robert C. Lieberman, Shifting the Color Line: Race and the American Welfare State, 2. printing, 1. paperback ed (Cambridge, Mass.: Harvard University Press, 1998/2001); Suzanne Mettler, Dividing Citizens: Gender and Federalism in New Deal Public Policy (Ithaca, N.Y: Cornell University Press, 1998); Jill S. Quadagno, The Color of Welfare: How Racism Undermined the War on Poverty (New York: Oxford Univ. Press, 1996).

${ }^{59}$ Mike Causey, "Griner Leads AFGE Ballot," The Washington Post, September 14, 1968, sec. Federal Diary; Mike Causey, "Rights Issues Stirs Revolts," The Washington Post, September 11, 1968, sec. Federal Diary.

${ }^{60}$ The federal government had banned employee strikes, thereby forcing unions to make these pledges and outraging many of their members. Mike Causey, "Union Votes Down Move to Drop No-Strike Vow," The Washington Post, September 12, 1968, sec. Federal Diary.

${ }^{61}$ Causey, "Griner Leads AFGE Ballot."

${ }^{62}$ Following Connolly, we give "sustained scholarly attention to what might seem to be fleeting moments" of Black Power to uncover an overlooked event in the historical material. By triangulating across several different sources (ibid), we are able to identify the 1968 convention as a major turning point in the history of the AFGE's political activism. Nathan D.B. Connolly, "A Black Power Method," Public Books, June 15, 2016, https://www.publicbooks.org/a-black-power-method/.

${ }^{63}$ In 1969, legislators introduced seven new bills in Congress concerning the wage board, compared to only four from 1967-1968. "Federal Wage Board Employees' Salary Increase, Legislative History," ProQuest Legislative Insight, accessed December 6, 2019, https://congressional-proquestcom.proxy.library.upenn.edu/legisinsight?id=PL92-392\&type=LEG_HIST. ${ }^{64}$ Mike Causey, "Senate Clears Blue-Collar Pay Raise," The Washington Post, September 11, 1970, sec. Federal Diary; Approximately 85,000 of these workers were employed by defense-related industries, see "Wage Board Employees" (Committee on Post Office and Civil Service. Senate; 91st Congress, 2nd Session (1970), August 31, 1970), https://congressional-proquestcom.proxy.library.upenn.edu/legisinsight?id=12881-5\%20S.rp.1155\&type=REPORT, 4 . ${ }^{65}$ See the statements of Macy, Rommel, and Wetzel in the Wage Board Employees Hearing. 66 "Wage Board Pay Rates,” Pub. L. No. Serial No. 91-14 (1969), https://congressional-proquestcom.proxy.library.upenn.edu/legisinsight?id=HRG-1969-POH-0021\&type=HEARING, 117

${ }^{67}$ Richard Nixon, "Proposing a Pay Increase, Message from the President," April 6, 1970, H. Doc. 91-298, 91st Congress, 2nd Session (1970), https://congressional-proquestcom.proxy.library.upenn.edu/legisinsight?id=12896-1\%20H.doc.298\&type=DOCUMENT.

${ }^{68} \mathrm{McGee}$ in "Wage Board Legislation," § Committee on Post Office and Civil Service. Senate (1971), https://congressional-proquest-com.proxy.library.upenn.edu/legisinsight?id=HRG-1971-POS0007\&type=HEARING, 1 .

69 "Pay System for Prevailing Rate Employees" (Committee on Post Office and Civil Service. House, 91st Congress, 2nd Session (1970), December 15, 1970), https://congressional-proquestcom.proxy.library.upenn.edu/legisinsight?id=12884-8\%20H.rp.1746\&type=REPORT.B

${ }^{70}$ Richard Nixon, "Veto of H.R. 17809, Message from the President of the United States Returning without Approval an Act (HR 17809) to Provide an Equitable System of for Fixing and Adjusting the Rates of Pay for Prevailing Rate Employees of the Government, and for Other Purposes," January 2, 1971, Document No. 91-437; on the employment of blue-collar workers in the military, see Mike Causey, "Convention Eyes Blue-Collar Unrest," The Washington Post, August 12, 1970, sec. The Federal Diary.

${ }^{71}$ See the discussion in Desmond King "Sectionalism and Policy Formation in the United States: President Carter's Welfare Initiatives,” British Journal of Political Science 26 (1996) 337-367.

72 "Wage Board Legislation,” § Committee on Post Office and Civil Service. Senate (1971), https://congressional-proquest-com.proxy.library.upenn.edu/legisinsight?id=HRG-1971-POS0007\&type=HEARING, 121. 
${ }^{73}$ Schweiker 92nd Congress, 2nd Session (1972), "Debated, Amended and Passed Senate" (Congressional Record, volume 118, June 15, 1972), https://congressional-proquestcom.proxy.library.upenn.edu/legisinsight?id=CR-1972-0615-PL92-392S\&type=CONGRESSIONAL RECORD, 21030

${ }^{74}$ Mike Causey, "Nixon Bids for Votes In Signing Pay Raise," The Washington Post, August 22, 1972, sec. Federal Diary; Mike Causey, "President of AFGE Endorses Nixon," The Washington Post, September 22, 1972, sec. Federal Diary.

${ }^{75}$ In the 1970s, about half of workers in wage grades one through four were Black, while less than a quarter of workers in General Schedule grades one through four were Black.

King, Separate and Unequal, 241.

${ }^{76}$ Wilson, Roscigno, and Huffman, "Racial Income Inequality and Public Sector Privatization."

77 Oliver, "Diverging Developments in Wage Inequality," 1556.

${ }^{78}$ On underpayment issues in the General Schedule, see Kearney and Mareschal, Labor Relations in the Public Sector, 185.

${ }^{79}$ Authors' calculations, using FedScope, "IBM Cognos PowerPlay Studio - Diversity - March 2018," 2018, https://www.fedscope.opm.gov/ibmcognos/cgi-bin/cognosisapi.dll.

${ }^{80}$ F. W. Gooding, Jr. American Dream Deferred: Black Federal Workers in Washington, DC, 1941-1981 (Pittsburgh, Pa: University of Pittsburgh Press, 2018), 10.

${ }^{81}$ Tarrow, Power in Movement; Tilly, Popular Contention in Great Britain, Piven and. Cloward, Poor People's Movements.

${ }^{82}$ See Clarissa Rile Hayward, "Disruption: What Is It Good For?," The Journal of Politics, January 31, 2020, 000-000, https://doi.org/10.1086/706766.

${ }^{83}$ Piven and Cloward, Poor People's Movements, 32.

${ }^{84}$ Philip F. Rubio, There's Always Work at the Post Office: African American Postal Workers and the Fight for Jobs, Justice, and Equality (Chapel Hill: University of North Carolina Press, 2010). F. W. Gooding, Jr. American Dream Deferred: Black Federal Workers in Washington, DC, 1941-1981 (Pittsburgh, Pa: University of Pittsburgh Press, 2018); Lee Ann Banaszak, The Women's Movement Inside and Outside the State (New York: Cambridge University Pres, 2010); Richard Valelly. Uncle Sam's Closet: Lesbian and Gay Enfranchisement and the American State, forthcoming.

${ }^{85}$ David Card, Thomas Lemieux, and W. Craig Riddell, "Unions and Wage Inequality: The Roles of Gender, Skill and Public Sector Employment" (Cambridge, MA: National Bureau of Economic Research, November 2018), https://doi.org/10.3386/w25313.

${ }^{86}$ Wilson, Roscigno, and Huffman, "Racial Income Inequality and Public Sector Privatization."

${ }^{87}$ Frank Dobbin and John R. Sutton, "The Strength of a Weak State: The Rights Revolution and the Rise of Human Resources Management Divisions," American Journal of Sociology 104, no. 2 (September 1998): 441-76, https://doi.org/10.1086/210044.

88 "Public Employee Unions," CQ Researcher vol 21 (April 8 2011) no 14: 316-336, at:

https://cepr.net/documents/CEPR_News/cqresearcher-042011.pdf

Complementary efforts legally to weaken union power over member and non-members have scored notable successes including the 2018 Supreme Court decision, Janus v. American Federation of State, City and Municipal Employees, Council No 31, No 16-1466, 585 U.S. (2018) permitting non-members to win exemption from fee contribution to a union.

${ }^{89}$ Alec MacGillis, "The Unelectable Whiteness of Scott Walker," The New Republic, June 15, 2014, https://newrepublic.com/article/118145/scott-walkers-toxic-racial-politics; Bill Martens, "New Republic Runs Critical Cover Story On Scott Walker," The Joy Cardin Show (Wisconsin Public Radio, June 19, 2014), https://www.wpr.org/new-republic-runs-critical-cover-story-scott-walker.

${ }^{90}$ Marc Dixon, "Limiting Labor: Business Political Mobilization and Union Setback in the States," Journal of Policy History 19, no. 3 (July 2007): 313-44, https://doi.org/10.1353/jph.2007.0015.

${ }_{91}$ Thomas B. Edsall, "Enter Scott Walker, Stage Right,” New York Times, April 29, 2015, https://www.nytimes.com/2015/04/29/opinion/thomas-b-edsall-repositioning-scott-walker.html.

${ }_{92}$ Walker and Bennett, "The Whiteness of Wisconsin's Wages," p 201; and for the broader context of this argument, see Dylan Bennett and Hannah Walker, "Cracking the Racial Code: Black Threat, White Rights and the Lexicon of American Politics," American Journal of Economics and Sociology 77 (2018): 689-727. 93 "Persons with a Disability: Labor Force Characteristics Summary," Bureau of Labor Statistics, February 26, 2019, https://www.bls.gov/news.release/disabl.nr0.htm; Drew DeSilver, "How Veterans and NonVeterans Fare in the U.S. Job Market," Pew Research Center (blog), September 17, 2019, 
https://www.pewresearch.org/fact-tank/2019/09/17/how-veterans-and-non-veterans-fare-in-the-u-s-jobmarket/.

${ }^{94}$ On gendered differences in wages in the general labor market, see U.S. Bureau of Labor Statistics, "Women in the Labor Force: A Databook," November 2017, https://www.bls.gov/opub/reports/womensdatabook/2017/pdf/home.pdf. Differences under the Federal Wage Schedule are available at: "Federal Workforce Data: Employment Cube," Fedscope, March 2019, https:/www.fedscope.opm.gov/. Note that women benefit from public sector employment cross-nationally, see: "Share of Public Sector Employment Filled by Women, 2009 and 2015," (:Unav), July 13, 2017, https://doi.org/10.1787/gov glance-2017graph50-en.

${ }_{95}$ Michael B Katz, Why don't American cities burn? (Philadelphia: University of Pennsylvania Press, 2012), http://public.eblib.com/choice/publicfullrecord.aspx?p=3441953, 60.

\section{Author Biographies}

Isabel M. Perera (iperera@upenn.edu ) is a postdoctoral fellow at the University of Pennsylvania. In 2020, she will join Cornell University as Assistant Professor of Government. Her work examines health, labor, and social policy in comparative and historical perspective.

Desmond King (desmond.king@,nuffield.ox.ac.uk) is the Andrew W. Mellon Professor of American Government at the University of Oxford and Professorial Fellow of Nuffield College. He specializes in the study of the American state in US executive politics, and racial inequality in American political development, and the financial bases of US politics. 